\title{
Granulosa Cell Tumors of the Ovary: A Retrospective Tertiary Center Experience
}

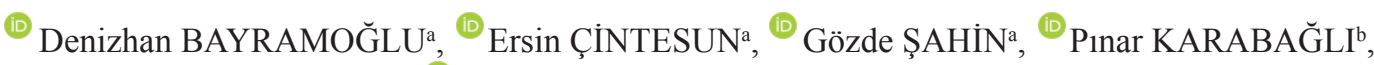 \\ (1) Zeynep BAYRAMOĞLUc, ${ }^{\circ}$ Çetin ÇELIK ${ }^{\mathrm{a}}$
}

aDepartment of Obstetrics and Gynecology, Selçuk University Faculty of Medicine, Konya, TURKEY

bepartment of Pathology, Selçuk University Faculty of Medicine, Konya, TURKEY

${ }^{\circ}$ Clinic of Pathology, Bağcılar Medipol Mega University Hospital, İstanbul, TURKEY

\begin{abstract}
Objective: Granulosa cell tumor (GCT) of the ovary is an uncommon neoplasm with good prognosis. GCT is a rare ovarian malignancy originating from sex cord-stromal cells. The only clinically proven prognostic factor regarding recurrence is stage. In this study, we aimed to analyze the detailed clinical and histopathological prognostic parameters of this rare malignancy, based on the cases we experienced in our own clinic. Material and Methods: Forty-six patients who were followed up and treated with the diagnosis of granulosa cell ovarian tumor between 2010 and 2020 were evaluated retrospectively by scanning the patient archive files. Results: The median follow-up period was 52 months. The mean patient age was 55 years. The most common symptom was abdominal pain. The most common surgical procedure was total abdominal hysterectomy+bilateral salpingo-oophorectomy+pelvic/paraaortic lymph node dissection with $60.9 \%$ ( $\mathrm{n}=28$ ). Fertility sparing surgery was performed for $5(10.9 \%)$ patients. In this study, a significant relationship was found between the survival and FIGO stage, nuclear atypia, mitotic rate. The rate of metastatic lymph nodes is very low in primary surgery and therefore may not be performed. Conclusion: GCT is one of the rare diseases of ovary. Since recurrence may occur even after many years, the follow-up period should be kept long. Stage is still the most important prognostic factor and is directly related to survival. In addition, the mitotic rate and nuclear atypia of the tumor may also be prognostic factors and have an impact on survival.
\end{abstract}

Keywords: Granulosa cell tumor; ovary; sex cord-stromal tumor; prognostic factor

Granulosa cell tumor (GCT) is a rare ovarian malignancy originating from sex cord-stromal cells. Sex cord stromal tumors account for 5-8\% of all ovarian malignancies. ${ }^{1}$ GCTs, which constitute approximately $70 \%$ of sex cord stromal ovarian tumors, are seen in $0.4-1.7$ per 100,000 women. They are divided into 2 sub-groups as juvenile (5\%) and adult (95\%) tumors based on their clinical presentation and histologic characteristics. The only clinically proven prognostic factor regarding recurrence is stage. However, patient age, tumor size, presence of intraperitoneal disease and the scope of the operation also play a role in prognosis. ${ }^{2}$ Histological prognostic factors include nuclear atypia and mitosis. ${ }^{3}$ Average recurrence is 5 years after surgery for the primary tumor. However, cases recurring even 20-30 years after the initial diagnosis have been reported in the literature. ${ }^{4}$

Only $2 \%$ of GCT cases are bilateral, and most cases are diagnosed at Stage 1. Synchronous GCT has also been reported very rarely. They are usually lowgrade tumors with good prognosis. The most common presentation includes abdominal pain and distention. ${ }^{5}$ Also they can secrete estrogen. Endometrial thickness should be evaluated with transvaginal ultrasound

Correspondence: Zeynep BAYRAMOĞLU

Clinic of Pathology, Bağcılar Medipol Mega University Hospital, İstanbul, TURKEY

E-mail: drzeynepbayramoglu@hotmail.com

Peer review under responsibility of Journal of Clinical Obstetrics \& Gynecology. 
(TVUSG) against the risk of endometrial cancer/hyperplasia, and endometrial biopsy should be performed when necessary.

Radiological view can be cystic or solid masses. Serum tumor markers such as inhibin, estradiol and antimullerian hormone can be used in the diagnosis and postoperative follow-up. ${ }^{6}$ The most sensitive and specific serum tumor marker used for diagnosing granulosa cell tumors is inhibin. Molecular and immunohistochemical studies are carried out to explain the mechanisms involved in the high grade transformation of GCTs. ${ }^{7}$ Final diagnosis is made by histological examination following surgical excision. Surgical staging of GCTs is made according to the classification defined by the FIGO.

Total abdominal hysterectomy and bilateral salpingo-oophorectomy (TAH+BSO) is usually performed in patients who completed their fertility while unilateral salpingo-oophorectomy can be performed conservatively in women who wish to have children. However, it is recommended that these patients are closely monitored and undergo complementary surgery after completing their fertility.

Surgery is the primary treatment at the early stage while adjuvant therapy with platinum-based chemotherapy combinations is recommended for high-risk (tumor rupture, high mitotic index, etc.) or advanced stage patients. Due to the rarity of the disease, experience and evidence for its treatment is limited. Therefore, the incidence of lymph node metastasis is not clearly known and the need for lymphadenectomy is controversial.

The aim of this study is to analyze the detailed clinical and histopathological prognostic parameters of this rare malignancy, based on the cases we experienced in our clinic.

\section{MATERIALAND METHODS}

In our study, we retrospectively analyzed 46 patients who were followed-up and treated with the diagnosis of granulosa cell ovarian tumor. Patient age, tumor type (adult/juvenile), tumor location, abdominal cytology status, stage of the disease according to FIGO classification, patients' admission complaints, hormonal status (pre-menopause/post-menopause), max- imum tumor size, radiological appearance of the tumor (cystic/solid), preoperative CA-125, type and date of surgery, endometrial pathology conditions, adjuvant treatment status, metastasis and recurrence areas, patients' living status, follow-up time and overall survival (OS), and inhibin positivity, presence of nuclear atypia and mitotic rates (10 HPFhigh-power fields) in pathology specimens were recorded. Mitotic rates of 6/10 HPF and above were evaluated as "high mitotic index" while values below 6/10 HPF were evaluated as "low mitotic index". As pre-operative radiological imaging methods, magnetic resonance imaging was used in some patients while ultrasonography was used in others.

During the study, the Helsinki Declaration was followed and Ethics Committee of Selcuk University Faculty of Medicine approved this study (approval number: 2020/152, approval date: 01.04.2020).

The patients' endometrial pathology states were obtained from the post-operative pathology reports if hysterectomy was performed, and from the pre-operative endometrial sampling reports if hysterectomy was not performed. Living status of patients was determined through patient follow-up files or central population management system records. Overall survival (OS) was defined as the time from diagnosis to death or last control.

Statistical analysis was performed using the Statistical Package for the Social Sciences (SPSS) version 21.0 software (IBM Corp., Armonk, NY, USA). Histogram and Shapiro-Wilk tests were used for the analysis of normal distribution. Continuous and discrete variables with normal distribution were presented with mean \pm standard deviation while those without normal distribution were presented with median (minimum-maximum) values. Categorical variables were expressed as numbers and percentages. Independent sample t-test or Mann-Whitney U test was used in pair group comparisons. The Pearson chisquare test and Fisher's exact test were used for the comparison of categorical variables. Kaplan-Meier analysis was performed in selected categories for survival analysis. Statistical significance level was accepted as $\mathrm{p}<0.05$. 


\section{RESULTS}

The study included a total of 46 patients. Median age was calculated as 55 years. Ninety one point three percent $(n=42)$ of the GCTs were adult type and $8.7 \%$ $(n=4)$ were juvenile type. The mean longest radiological tumor diameter was $98.2 \mathrm{~mm}$. In terms of hormonal status, $34.8 \%(n=16)$ of the patients were premenopausal and $65.5 \% \quad(\mathrm{n}=30)$ were postmenopausal. Most common symptoms were abdominal pain with $41.3 \%(\mathrm{n}=19)$ and postmenopausal bleeding with $32.6 \%(n=15)$. Radiological appearance of the tumor was reported as cystic+solid in $43.5 \%(n=20)$ patients. CA-125 values were within normal limits in $76.1 \%(n=35)$ of the patients. The patient characteristics are listed in Table 1.

According to FIGO staging, $76 \%$ of the patients $(\mathrm{n}=35)$ were Stage 1A, 2.2\% ( $\mathrm{n}=1)$ Stage 1C1, 10.9\% $(n=5)$ Stage 3A1 and 10.9\% $(n=5)$ Stage 3C. The most common surgical procedure was $\mathrm{TAH}+\mathrm{BSO}+$ pelvic/paraaortic lymph node dissection+omentectomy with $60.9 \%(\mathrm{n}=28)$. Metastasis sites were reported as pelvic+paraaortic lymph nodes in 2 patients, and omentum+peritoneum surface in the other 2 patients. During the follow-up period, only $2.2 \%(n=1)$ of the patients had recurrence. The most common concomitant endometrial pathology was endometrial polyp with $15.2 \%(\mathrm{n}=7)$. In addition, $8.7 \%$ $(n=4)$ had endometrial cancer. The surgical pathological features are given in Table 1.

The rate of patients who received adjuvant therapy was $13.0 \%(n=6)$. While all 6 patients who received adjuvant therapy received chemotherapy, none of the patients received radiotherapy. As the chemotherapy regimen, 3 patients were given cisplatin+etoposide+bleomycin, 2 patients paclitaxel+carboplatin, and 1 patient cyclophosphamide + doxorubicin +5 -fluorouracil.

Considering age and survival, there was no statistically significant difference in OS between patients younger than 50 years of age and older $(p=0.807)$ (Figure 1a). Considering tumor size and survival, there was no statistically significant difference in survival between tumors $<10 \mathrm{~cm}$ and $\geq 10 \mathrm{~cm}$ $(\mathrm{p}=0.752)$ (Figure 1b). CA-125 and survival: No sta-
TABLE 1: Baseline characteristics of patients.

n $(\%)$

Age (years)
Median
$<50$
$\geq 50$
Tumor type

Adult $\quad 42(91.3)$

Juvenil $\quad 4(8.7)$

Tumor size (cm)

$<10 \quad 26(56.5)$

$\geq 10 \quad 20(43.5)$

Hormonal status

Premenopausal $16(34.8)$

Postmenopausal $\quad 30(65.2)$

Symptoms

Abdominal pain $19(41.3)$

Postmenopausal bleeding $15(32.6)$

Abnormal uterin bleeding $6(13.0)$

Pelvicmass $4(8.7)$

Menstruel abnormalities $2(4.3)$

Radiological view

Cystic $11(23.9)$

Solid $15(32.6)$

Cystic+solid 20 (43.5)

Serum CA-125 level

Normal $(\leq 35 \mathrm{U} / \mathrm{mL})$

Elevated $(>35 \mathrm{U} / \mathrm{mL}) \quad 11(23.9)$

Status

Death $\quad 5(10.9)$

Alive $\quad 41$ (89.1)

FIGO stage

Stage $1 \mathrm{~A} \quad 35(76.1)$

Stage $1 \mathrm{C} 1$

Stage 3A1 $5(10.9)$

Stage $3 C \quad 5(10.9)$

Surgical procedure

TAH+BSO+PPLND+omentectomy $28(60.9)$

TAH+BSO $9(19.6)$

USO $4(8.7)$

TAH+BSO+PPLND+omentectomy+appendectomy $3(6.5)$

USO+PPLND+omentectomy $1(2.2)$

TAH+USO $1(2.2)$

Lymphadenectomy (PPLND)

Yes $32(69.5)$

No

$14(30.5)$

Tumor side

Unilateral $\quad 46(100)$

Bilateral $0(0)$ 


\begin{tabular}{lc|}
\hline \multicolumn{2}{|l|}{ TABLE 1: Baseline characteristics of patients (continued). } \\
\hline \multicolumn{1}{l}{ n (\%) } \\
Cytology \\
Positive & $4(8.7)$ \\
Negative & $42(91.3)$ \\
Endometrial pathology & \\
Normal & $30(65.2)$ \\
Endometrial polyp & $7(15.2)$ \\
Endometrial cancer & $4(8.7)$ \\
Simple hyperplasia with out atypia & $3(6.5)$ \\
Adenomyosis & $2(4.3)$ \\
Metastasis & \\
Yes & $4(8.7)$ \\
No & $42(91.3)$ \\
Recurrence & \\
Yes & $1(2.2)$ \\
No & $45(97.8)$ \\
Mitotic rate & \\
$<6 / 10$ HPF & $26(56.5)$ \\
$\geq 6 / 10$ HPF & $20(43.5)$ \\
Inhibin (IHC) & \\
Yes & $46(100)$ \\
No & $0(0)$ \\
Nuclearatypia & \\
Positive & $27(58.7)$ \\
\hline
\end{tabular}

TAH+BSO: Total abdominal hysterectomy and bilateral salpingo-oophorectomy; PPLND: Pelvic/paraaortic lymph node dissection; USO: Unilateral salpingo-oophorectomy; HPF: High-power field; IHC: Immunohistochemistry.

tistically significant difference was found in the mean survival time between the patients with normal and high CA-125 levels $(\mathrm{p}=0.070)$ (Figure 1c).

When we look at the relationship between nuclear atypia and survival, a statistically significant difference in survival was found between tumors with and without nuclear atypia $(\mathrm{p}=0.044)$. Tumors with nuclear atypia had shorter survival (Figure 2a). A detailed review of the survival analysis is summarized in Table 2. Stage and survival: The survival analysis was performed for FIGO Stage 1 (early stage) and FIGO Stage 2-4 (advanced stage). The patients with early stage had a longer survival than those with advanced stages $(p=0.001)$ (Figure $2 b)$. When we look at the relationship between mitosis ratio and survival, there was a significant difference in survival between the patients with low mitotic index and high mitotic index $(\mathrm{p}=0.018)$. Patients with low mitotic index had longer survival than the patients with high mitotic index (Figure 2c). The mean follow-up time was 52 months (7-118). At the end of the follow-up, $89.1 \%$ $(n=41)$ of the patients were still alive, while $10.9 \%$ $(\mathrm{n}=5)$ died (Table 1). Three year OS was determined as $95 \%$ and 5 -year OS as $92 \%$ (Figure 3).

\section{DISCUSSION}

As in other rare diseases, a detailed information on GCT and its optimal management is limited. There is a limited amount of research and participants due to the low incidence of the disease, which has made it difficult to establish a standard management scheme. Of patients, $81 \%$ are diagnosed at early stages $(71 \%$ Stage $1,10 \%$ Stage 2 ) and $19 \%$ are diagnosed at advanced stages (11\% Stage 3, 8\% Stage 4). ${ }^{8}$ In accordance with the literature, $78.2 \%$ of our cases were detected at an early stage. In a study in which all ovarian neoplasms were examined and 957 patients were evaluated, it was reported that only $24(2.51 \%)$ patients had GCT. ${ }^{9}$

The mean follow-up period was 52 months in our study. Although the number of patients and fol-

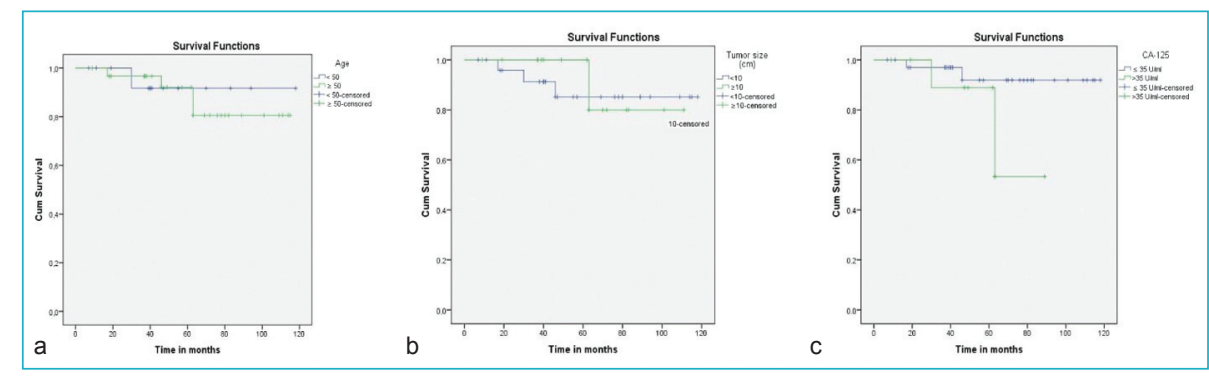

FIGURE 1: a) Age and survival, b) Tumor size and survival, c) CA-125 value and survival. 


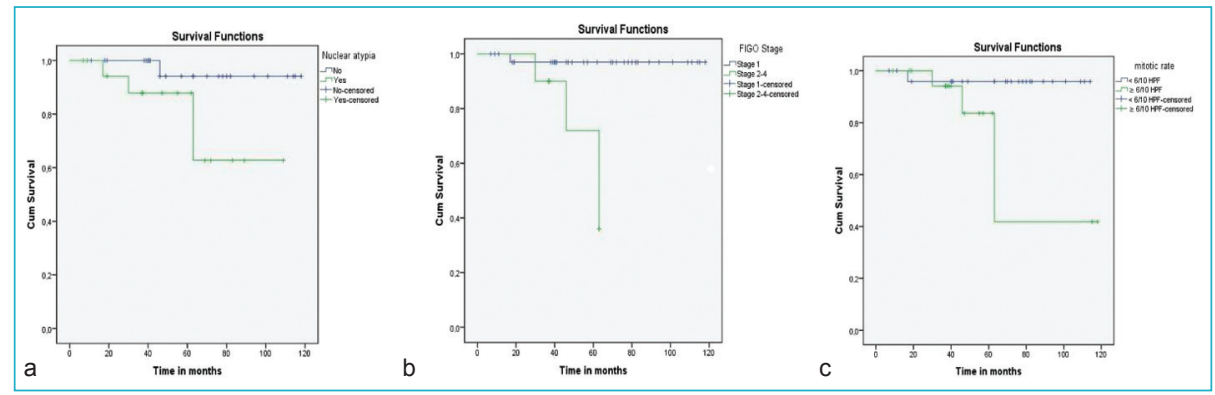

FIGURE 2: a) Nuclear atypia and survival b) Stage and survival c) Mitotic rate and survival.

\begin{tabular}{|c|c|c|c|c|c|}
\hline & & Mean estimate $(95 \% \mathrm{Cl})$ & Standard error & Chi-square & $p$ value \\
\hline \multirow[t]{2}{*}{ Age } & $<50$ & 110,667 & & 0.060 & 0.807 \\
\hline & $\geq 50$ & 102.573 & & & \\
\hline \multirow[t]{2}{*}{ Mitotic rate } & $<6 / 10 \mathrm{HPF}$ & $109.958(102.203-117.713)$ & 3.957 & 5.607 & 0.018 \\
\hline & $\geq 6 / 10 \mathrm{HPF}$ & $82.288(57.370-107.206)$ & 12.713 & & \\
\hline \multirow[t]{2}{*}{ FIGO stage } & Stage 1 & $114.939(109.032-120.847)$ & 3.014 & 10.399 & 0.001 \\
\hline & Stage 2-4 & $56.640(47.765-65.515)$ & 4.528 & & \\
\hline \multirow[t]{2}{*}{ CA-125 } & $\leq 35 \mathrm{U} / \mathrm{mL}$ & 111.265 (102.239-120.291) & 4.605 & 3.293 & 0.070 \\
\hline & $>35 \mathrm{U} / \mathrm{mL}$ & $73.200(59.126-87.274)$ & 7.180 & & \\
\hline \multirow[t]{2}{*}{ Tumor size } & $<10 \mathrm{~cm}$ & 105.395 (92.131-118.659) & 6.767 & 0.100 & 0.752 \\
\hline & $\geq 10 \mathrm{~cm}$ & $101.400(89.500-113.300)$ & 6.072 & & \\
\hline \multirow[t]{2}{*}{ Nuclear atypia } & Yes & 87.086 (69.381-104.791) & 9.033 & 4.054 & 0.044 \\
\hline & No & $113.765(105.711-121.818)$ & 4.109 & & \\
\hline
\end{tabular}

Cl: Confidence interval.

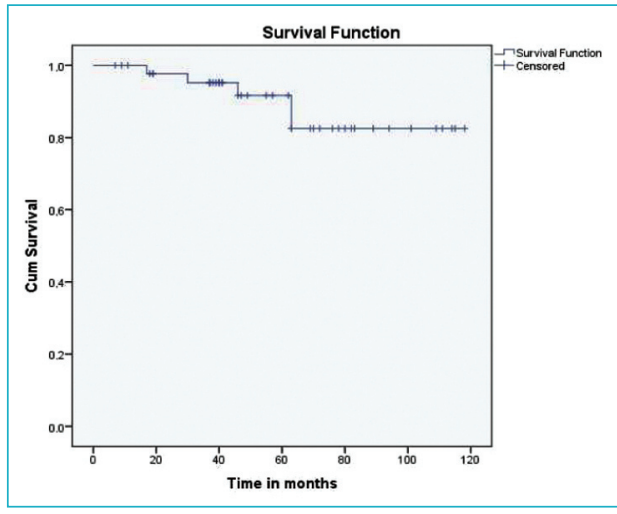

FIGURE 3: Overall survival.

low-up period seem to be insufficient, they are comparable to similar studies in the literature. The mean age of the patients ranges between 50-54 and it was calculated as in our study. ${ }^{10}$ Consistent with the literature, the most reported symptom was abdominal pain among our cases $(41.3 \%)$. While the main symp- tom observed in our premenopausal patients was abdominal pain, complaints related to vaginal bleeding were more prominent in our postmenopausal patients. It has been reported that there are rarely GCTs presenting with ovarian torsion. ${ }^{11,12}$

CA-125, a tumor marker used in epithelial ovarian cancer, does not increase in GCT patients and there is no significant difference in serum levels in early or advanced cases. ${ }^{13}$ CA-125 level was high only $23.9 \%$ of our patients. In addition, our analysis revealed that the patients with normal and high CA125 values did not show a statistically significant difference in survival.

Surgery is the gold standard treatment where staging surgery is performed together with $\mathrm{TAH}+\mathrm{BSO}$ in early stages, while debulking surgery is applied in patients with advanced or recurrent GCT. We also performed staging surgery, including lymph 
node dissection, in the majority of our cases (Table 2). However, our lymph node dissection consisted of removing the detected bulky lymph nodes and excising the suspicious nodes rather than a complete dissection.

There are also controversial studies supporting that lymph node dissection should be performed in addition to the surgery as well as those that object to it. ${ }^{14-16}$ Reviewing relevant studies in the literature, it is seen that the rate of metastatic lymph nodes is approximately $4.4 \%$ in patients who undergo lymph node dissection (Table 3). ${ }^{17-19}$ This suggests that the rate of metastatic lymph nodes is very low in primary surgery and therefore may not be performed. In our study, although lymph node dissection was performed in $32(69.5 \%)$ patients, pelvic and paraaortic lymph node metastases were detected in only $2(4.3 \%)$ patients. This rate was determined as $6.2 \%$ by taking into account only the patients undergoing lymph node dissection. The rate in our study was similar to the rates in the literature.

The Current National Comprehensive Cancer Network guideline recommends adjuvant chemotherapy for patients with advanced stage or early stage but high risk factors, however, the definition of "highrisk patient" is not clear. Both studies conducted by Mangili et al. and Wang et al. revealed that adjuvant chemotherapy was not beneficial in patients with early-stage GCT, that is, it did not protect patients from recurrence or improve survival. ${ }^{20,21}$ In our study, most of the patients were followed up without adjuvant chemotherapy, and only $6(13 \%)$ patients received adjuvant chemotherapy. BEP (bleomycin, etoposide, cisplatin), the most commonly used chemotherapy regimen, was applied to 3 of our 6 patients receiving chemotherapy. ${ }^{22}$

\begin{tabular}{|lcc|}
\hline \multicolumn{3}{|c|}{ TABLE 3: $\begin{array}{c}\text { Lymph node excisions and metastasis } \\
\text { rates in the literature. }\end{array}$} \\
\hline Study & Lymph node disection cases & Metastatic node (+) \\
Karalok et al. ${ }^{17}$ & 121 & $3(2.5 \%)$ \\
\hline Ayhan et al. ${ }^{13}$ & 80 & $7(8.8 \%)$ \\
\hline Ertas et al. ${ }^{18}$ & 58 & $3(5.1 \%)$ \\
Brown et al. ${ }^{19}$ & 36 & $0(0 \%)$ \\
\hline Total & 295 & $13(4.4 \%)$ \\
Our study & 32 & $2(6.2 \%)$ \\
\hline
\end{tabular}

Fertility-sparing approaches should also be taken into account in the treatment plan since GCT also affects young patients. Although some of the studies on fertility-sparing approaches state that these patients have higher recurrence and lower survival rates, on the contrary, other studies indicate that they have similar results with radical surgery. ${ }^{20,23,24}$ In our study, a total of $5(10.9 \%)$ patients underwent fertility-sparing surgery, but no recurrence or death was observed during the follow-up period.

GCT patients can develop endometrial hyperplasia or endometrial cancer when exposed to high and long-term exposure to estrogen secreted by tumor tissue. ${ }^{25}$ The incidence of this risk ranges from $21 \%$ to $71 \%$ for endometrial hyperplasia and $1.3 \%$ to $13.2 \%$ for endometrial cancer in the literature. ${ }^{26} \mathrm{In}$ our study, endometrial cancer was detected in 4 $(8.7 \%)$ patients. The risk of any endometrial pathology is very low following the removal of the tumor tissue in patients whose uterus and intact ovaries are left untouched with fertility-sparing surgery. Moreover, spontaneous regression can be observed in existing endometrial pathologies. ${ }^{27}$ However, the endometrium should be closely monitored with TVUSG and curettage in young patients.

The rate of recurrence is approximately $25 \%$ and usually occurs in 5-10 years. The time interval for the latest GCT recurrence reported in the literature is 40 years. Therefore, clinical follow-ups of GCT patients should not be terminated early and should be continued life-long. Local pelvic recurrence accounts for $70 \%$ of cases while $9 \%$ of recurrences are abdominopelvic, $6 \%$ retroperitoneal, $6 \%$ pelvic and retroperitoneal, and 3\% abdominopelvic and retroperitoneal. ${ }^{28}$ In our study, recurrence was detected in only $1(2.2 \%)$ patient in the $39^{\text {th }}$ month of the follow-up and in the right adnexal area.

Some studies have revealed several risk factors such as advanced age, large tumor size, tumor rupture, lymphovascular area invasion, degree of cytological atypia, and high mitotic index...$^{2029-33}$ The results of these studies do not fully match with others and remain controversial. In our study, low mitotic index, early FIGO Stage and absence of nuclear atypia were associated with better survival outcomes. 
It should be known that these studies have several disadvantages such as patient heterogeneity, limited number of patients, and short follow-up times.

The stage is the most important prognostic factor on survival. Previous studies reported that 5-year OS rates generally ranged from $75 \%$ to $95 \%$ for early stage and $25 \%$ to $50 \%$ for advanced stage. Approximately $80 \%$ of our patients were detected at early stages, and 3-year and 5-year OS rates were calculated as $95 \%$ and $92 \%$, respectively. Our analysis also supported the existence of a significant relationship between FIGO stage and survival, which was in accordance with the literature.

A definite effect of age on recurrence, diseasefree survival and OS of GCT patients could not be demonstrated. ${ }^{15,20}$ Zhang et al. ${ }^{31}$ reported that patients under the age of 50 have a $10 \%$ longer survival rate while Ayhan et al. ${ }^{13}$ reported that patients under the age of 60 have a longer survival. ${ }^{13,21,27,28}$ Contrarily, Bryk et al. reported that patients with age $<40$ have higher recurrence rate. ${ }^{32}$ We could not find a significant relationship between age and survival rates in our study.

Although average tumor size is $10 \mathrm{~cm}$, they can also be larger masses that fill the abdomen. Thrall et al. reported that the most important factor in predicting disease mortality in patients with GCT is tumor size while reporting no recurrence in tumors smaller than $7 \mathrm{~cm} .{ }^{15}$ Tumor size was identified as an important prognostic factor in many studies. ${ }^{13,30,31}$ These studies show that a tumor with a size of $10-15 \mathrm{~cm}$ is associated with increased recurrence and mortality rates. Conversely, some other studies stated that tumor size is not as an important prognostic factor as FIGO stage. ${ }^{13,33}$ Our analysis revealed no significant difference between tumor size and survival.

The retrospective design, limited number of patients and short follow-op period were the limitations of our study. However, our patient number and follow-up period were comparable to major studies in the literature.

Prospective randomized controlled studies with larger numbers of patients and longer follow-up pe- riods are needed to understand better the GCT disease and to establish a standardized treatment and follow-up system.

\section{CONCLUSION}

In conclusion, our study showed us that GCTs occur rarely, the patients should be followed up for extended periods due to the probability of late recurrence, lymph node dissection is not a mandatory part of the surgical treatment, stage is still the most important prognostic factor in GCT cases and is directly related to survival, while, in addition, mitosis ratio and nuclear atypia may also be prognostic factors and may have an impact on survival.

\section{Source of Finance}

During this study, no financial or spiritual support was received neither from any pharmaceutical company that has a direct connection with the research subject, nor from a company that provides or produces medical instruments and materials which may negatively affect the evaluation process of this study.

\section{Conflict of Interest}

No conflicts of interest between the authors and / or family members of the scientific and medical committee members or members of the potential conflicts of interest, counseling, expertise, working conditions, share holding and similar situations in any firm.

\section{Authorship Contributions}

Idea/Concept: Denizhan Bayramoğlu, Ersin Çintesun, Gözde Şahin, Çetin Çelik; Design: Denizhan Bayramoğlu, Zeynep Bayramoğlu, Ersin Çintesun; Control/Supervision: Denizhan Bayramoğlu, Ersin Çintesun, Pınar Karabağll, Çetin Çelik; Data Collection and/or Processing: Denizhan Bayramoğlu, Gözde Şahin, Pınar Karabağll, Çetin Çelik; Analysis and/or Interpretation: Denizhan Bayramoğlu, Zeynep Bayramoğlu, Ersin Çintesun, Gözde Şahin; Literature Review: Denizhan Bayramoğlu, Zeynep Bayramoğlu, Çetin Çelik; Writing the Article: Denizhan Bayramoğlu, Zeynep Bayramoğlu, Pınar Karabağll; Critical Review: Denizhan Bayramoğlu, Zeynep Bayramoğlu, Çetin Çelik; References and Fundings: Denizhan Bayramoğlu, Zeynep Bayramoğlu, Çetin Çelik; Materials: Denizhan Bayramoğlu, Çetin Çelik, Zeynep Bayramoğlu, Ersin Çintesun. 


\section{REFERENCES}

1. Schumer ST, Cannistra SA. Granulosa cell tumor of the ovary. J Clin Oncol. 2003;21(6): 1180-9. [Crossref] [PubMed]

2. Pankratz E, Boyes DA, White GW, Galliford BW, Fairey RN, Benedet JL. Granulosa cell tumors. A clinical review of 61 cases. Obstet Gynecol. 1978;52(6):718-23. [PubMed]

3. Goldston WR, Johnston WW, Fetter BF, Parker RT, Wilbanks GD. Clinicopathologic studies in feminizing tumors of the ovary. I. Some aspects of the pathology and therapy of granulosa cell tumors. Am J Obstet Gynecol. 1972;112(3):422-9. [Crossref] [PubMed]

4. Hines JF, Khalifa MA, Moore JL, Fine KP, Lage JM, Barnes WA. Recurrent granulosa cell tumor of the ovary 37 years after initial diagnosis: a case report and review of the literature. Gynecol Oncol. 1996;60(3):484-8. [Crossref] [PubMed]

5. Ashnagar A, Alavi S, Nilipour Y, Azma R, Falahati F. Massive ascites as the only sign of ovarian juvenile granulosa cell tumor in an adolescent: a case report and a review of the literature. Case Rep Oncol Med. 2013;2013: 386725. [Crossref] [PubMed] [PMC]

6. Mom $\mathrm{CH}$, Engelen MJ, Willemse PH, Gietema JA, ten Hoor KA, de Vries EG, et al. Granulosa cell tumors of the ovary: the clinical value of serum inhibin $A$ and $B$ levels in a large single center cohort. Gynecol Oncol. 2007; 105(2):365-72. [Crossref] [PubMed]

7. Gogola J, Hoffmann M, Ptak A. Persistent endocrine-disrupting chemicals found in human follicular fluid stimulate IGF1 secretion by adult ovarian granulosa cell tumor spheroids and thereby increase proliferation of non-cancer ovarian granulosa cells. Toxicol In Vitro. 2020;65:104769. [Crossref] [PubMed]

8. Kottarathil VD, Antony MA, Nair IR, Pavithran $\mathrm{K}$. Recent advances in granulosa cell tumor ovary: a review. Indian J Surg Oncol. 2013; 4(1):37-47. [Crossref] [PubMed] [PMC]

9. Mondal SK, Banyopadhyay R, Nag DR, Roychowdhury S, Mondal PK, Sinha SK. Histologic pattern, bilaterality and clinical evaluation of 957 ovarian neoplasms: a 10-year study in a tertiary hospital of eastern India. J Cancer Res Ther. 2011;7(4):433-7. [Crossref] [PubMed]

10. Sekkate S, Kairouani M, Serji B, M'Rabti H, El Ghissassi I, Errihani H. Les tumeurs de la granulosa de l'ovaire [Granulosa cell tumors of the ovary]. Bull Cancer. 2014;101(1):93101. French. [Crossref] [PubMed]

11. Siviero I, da Silva de Oliveira JT, Forny DN,
Méio IB, Bertrand Simões BC, Rezende Penna CR, et al. Torsion of granulosa cell tumor of the ovary in a preschool patient: a rare cause of acute abdomen. Am J Case Rep. 2020;21:e921689. [Crossref] [PubMed] [PMC]

12. Mohapatra A, Chaudhry R, Picarsic J, Schneck FX. A rare case of uterine torsion with juvenile granulosa cell tumor in the pediatric patient. Urology. 2019;128:87-9. [Crossref] [PubMed]

13. Ayhan A, Salman MC, Velipasaoglu M, Sakinci M, Yuce K. Prognostic factors in adult granulosa cell tumors of the ovary: a retrospective analysis of 80 cases. J Gynecol Oncol. 2009;20(3):158-63. [Crossref] [PubMed] [PMC

14. Shim SH, Lee SJ, Kim DY, Kim J, Kim SN, Kang SB, et al. A Long-term follow-up study of 91 cases with ovarian granulosa cell tumors. Anticancer Res. 2014;34(2):1001-10. [PubMed]

15. Thrall MM, Paley P, Pizer E, Garcia R, Goff BA. Patterns of spread and recurrence of sex cord-stromal tumors of the ovary. Gynecol Oncol. 2011;122(2):242-5. [Crossref] [PubMed] [PMC]

16. Gurumurthy M, Bryant A, Shanbhag S. Effectiveness of different treatment modalities for the management of adult-onset granulosa cell tumours of the ovary (primary and recurrent). Cochrane Database Syst Rev. 2014;2014(4): CD006912. [Crossref] [PubMed] [PMC]

17. Karalok A, Turan T, Ureyen I, Tasci T, Basaran D, Koc S, et al. Prognostic factors in adult granulosa cell tumor: a long follow-up at a single center. Int J Gynecol Cancer. 2016;26(4): 619-25. [Crossref] [PubMed]

18. Ertas IE, Gungorduk K, Taskin S, Akman L, Ozdemir A, Goklu R, et al. Prognostic predictors and spread patterns in adult ovarian granulosa cell tumors: a multicenter longterm follow-up study of 108 patients. Int J Clin Oncol. 2014; 19(5):912-20. [Crossref] [PubMed]

19. Brown J, Sood AK, Deavers MT, Milojevic L, Gershenson DM. Patterns of metastasis in sex cord-stromal tumors of the ovary: can routine staging lymphadenectomy be omitted? Gynecol Oncol. 2009;113(1):86-90. [Crossref] [PubMed]

20. Mangili G, Ottolina J, Cormio G, Loizzi V, De laco $\mathrm{P}$, Pellegrini DA, et al. Adjuvant chemotherapy does not improve disease-free survival in FIGO stage IC ovarian granulosa cell tumors: The MITO-9 study. Gynecol
Oncol. 2016;143(2):276-80. [Crossref] [PubMed]

21. Wang $D$, Xiang $Y$, Wu M, Shen $K$, Yang J, Huang $\mathrm{H}$, et al. Is adjuvant chemotherapy beneficial for patients with FIGO stage IC adult granulosa cell tumor of the ovary? J Ovarian Res. 2018;11(1): 25. [Crossref] [PubMed] [PMC]

22. Ellouze S, Krichen-Makni S, Trabelsi K, Ayadi L, Sellami A, Khabir A, et al. Tumeur de la granulosa de l'ovaire: à propos de 16 cas [Granulosa-cell tumor of the ovary: report of 16 cases]. J Gynecol Obstet Biol Reprod (Paris). 2006;35(8 Pt 1):767-72. French. [Crossref] [PubMed]

23. Pautier $P$, Lhommé $C$, Culine $S$, Duvillard $P$, Michel G, Bidart JM, et al. Adult granulosacell tumor of the ovary: a retrospective study of 45 cases. Int $\mathrm{J}$ Gynecol Cancer. 1997;7(1):58-65. [Crossref] [PubMed]

24. Rinne N, Farthing A, Borley J. Fertility sparing surgery in advanced and recurrent granulosa cell tumours of the ovary. J Obstet Gynaecol. 2018; 38(1):143-5. [Crossref] [PubMed]

25. Szewczuk W, Szewczuk O, Czajkowski K, Grala B, Semczuk A. Ovarian adult-type granulosa cell tumor concomitant with simple endometrial hyperplasia: a case study with selected immunohistochemistry. J Int Med Res. 2020;48(4):300. [Crossref] [PubMed] [PMC]

26. Ottolina J, Ferrandina G, Gadducci A, Scollo $P$, Lorusso $D$, Giorda $G$, et al. Is the endometrial evaluation routinely required in patients with adult granulosa cell tumors of the ovary? Gynecol Oncol. 2015;136(2):230-4. [Crossref] [PubMed]

27. van Meurs HS, Bleeker MC, van der Velden J, Overbeek LI, Kenter GG, Buist MR. The incidence of endometrial hyperplasia and cancer in 1031 patients with a granulosa cell tumor of the ovary: long-term follow-up in a population-based cohort study. Int J Gynecol Cancer. 2013;23(8): 1417-22. [Crossref] [PubMed]

28. Abu-Rustum NR, Restivo A, Ivy J, Soslow R, Sabbatini P, Sonoda Y, et al. Retroperitoneal nodal metastasis in primary and recurrent granulosa cell tumors of the ovary. Gynecol Oncol. 2006;103(1):31-4. [Crossref] [PubMed]

29. Iyibozkurt AC, Topuz S, Gungor F, Akhan SE, Demirci F, Salihoglu Y, et al. Factors affecting recurrence and disease-free survival in granulosa cell tumors of the ovary. Eur J Gynaecol Oncol. 2010;31(6):667-71. [PubMed] 
30. Thomakos N, Biliatis I, Koutroumpa I, Sotiropoulou M, Bamias A, Liontos M, et al. Prognostic factors for recurrence in early stage adult granulosa cell tumor of the ovary. Arch Gynecol Obstet. 2016;294(5):1031-6. [Crossref] [PubMed]

31. Zhang M, Cheung MK, Shin JY, Kapp DS, Husain A, Teng NN, et al. Prognostic factors re- sponsible for survival in sex cord stromal tumors of the ovary--an analysis of 376 women. Gynecol Oncol. 2007;104(2):396-400. [Crossref] [PubMed]

32. Bryk S, Färkkilä A, Bützow R, Leminen A, Tapper J, Heikinheimo M, et al. Characteristics and outcome of recurrence in molecularly defined adult-type ovarian granulosa cell tumors.
Gynecol Oncol. 2016;143(3):571-7. [Crossref] [PubMed]

33. Nasioudis D, Kanninen TT, Holcomb K, Sisti G, Witkin SS. Prevalence of lymph node metastasis and prognostic significance of lymphadenectomy in apparent early-stage malignant ovarian sex cord-stromal tumors. Gynecol Oncol. 2017; 145(2):243-7. [Crossref] [PubMed] 